July - December 2018
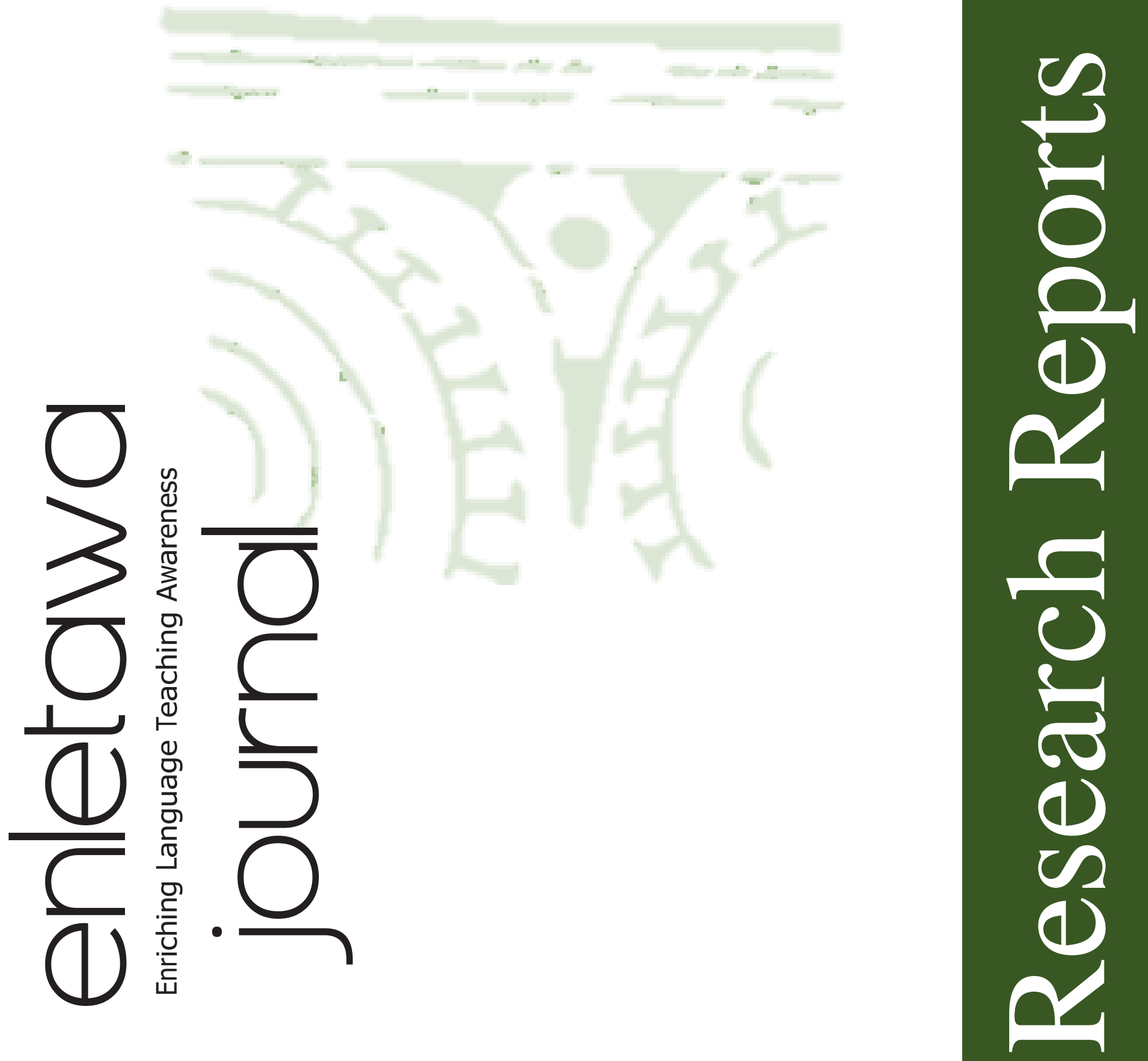

Vol. 11, No. 2 


\title{
Dear Someone: Connecting Medical Students and Rural Elementary School Students Through Pen Pal Letters ${ }^{1}$
}

\section{Querido alguien: Conectando a los estudiantes de medicina y estudiantes de primaria de áreas rurales a través de cartas de intercambio}

\author{
Anna Carolina Peñaloza ${ }^{2}$ \\ Universidad Pedagógica y Tecnológica de Colombia \\ anna.penaloza@uptc.edu.co \\ Ana Olga Rallón ${ }^{3}$ \\ Universidad Pedagógica y Tecnológica de Colombia \\ ana.rallon@uptc.edu.co
}

\section{Received: October 15, 2018}

\section{Accepted: November 4, 2018}

How to cite this article (APA, $6^{\text {th }}$ ed.): Peñaloza, A.C., \& Rallón, A. O. (2018). Dear someone: Connecting medical students and rural elementary school students through pen pal letters. Enletawa Journal, 11(2), 13-29.

\begin{abstract}
The following case study describes and interprets pen pal letter exchanges between medical students and rural elementary school students. This study was carried out with three third and fourth semester medical students at a public university in Tunja, Colombia. In addition, we also worked with a group of five elementary school girls from a rural community located 20 minutes from the university. Both groups participated in exchanging pen pal letters in English as a way to foster the sociocultural competence in communication. In order to analyze the communication established between the participants, we used students' artifacts, field notes, and reflective discussions. The findings revealed that the students' fostered authentic communication based on the language they

\footnotetext{
${ }^{1}$ Research Report

${ }^{2}$ Anna Carolina Peñaloza is the Academic Writing teacher for the International Language Institute at the Universidad Pedagógica y Tecnológica de Colombia (UPTC). She is a University of Arizona graduate from the College of Agriculture and Life Sciences, and she is currently studying her master's in Language Teaching at the UPTC. Anna belongs to the research group "TONGUE", and she is involved in community outreach for children and undergraduates.

${ }^{3}$ Ana Olga Rallón is an English teacher at the Universidad Pedagógica y Tecnológica de Colombia. She studied education, humanities, and arts at the University of Arizona and Pima Community College. Ana has worked with students from all ages and backgrounds, and in 2015, she started a community service program for young adults and children in her community. Her interests include community service, history, critical literacy, and interculturality.
} 
wanted to convey. As the communication between the students developed, instances of affiliates, advice giving, imitation, modeling, and empathy appeared. The pen pal letters showed that both groups are in a crucial period of identity construction, for which pen pal letters can help empower students and model positive behavior.

Key words: Pen pal letters, medical students, rural elementary students, empathy, role model, identity, and imitation.

\section{Resumen}

El siguiente estudio de caso describe e interpreta cartas de intercambio entre estudiantes de medicina y estudiantes de primaria de zona rural. Este estudio se llevó acabo con tres estudiantes de medicina de tercer y cuarto semestre de una universidad pública en Tunja, Colombia. Además, se trabajó con un grupo de cinco estudiantes de primaria de una comunidad rural a 20 minutos de la universidad. Ambos grupos participaron en el intercambio de cartas en inglés como una forma de cultivar competencias comunicativas socioculturales. Para analizar la comunicación establecida entre los participantes, utilizamos artefactos, diarios de campo y discusiones de reflexión. Los resultados revelaron que los estudiantes fomentaron una comunicación autentica según el tipo de lenguaje que querían expresar. A medida que la comunicación entre los estudiantes se desarrolló, se encontró ejemplos de amistad, consejos, imitación, modelos y empatía. El intercambio de cartas demostró que ambos grupos están en un periodo crucial en sus vidas en la construcción de identidad, y este tipo de correspondencia les otorgó una mayor conciencia de sí mismos y promovió modelos positivos.

Palabras clave: Cartas de intercambio, estudiantes de medicina, estudiantes rurales de primaria, empatía, modelos a seguir, identidad, e imitación. 


\section{Introduction}

As language teachers, we are often asked to teach language for its linguistic purposes, such as semantics, syntax, and phonetics. In teaching language from a linguistic perspective, we lose sight of what it really means to communicate. Communication is "a transmission of verbal and non-verbal messages. It consists of a sender, receiver, and channel of communication", and it "requires full understanding of behaviors associated with the sender and receiver" (Munodawafa, 2008, p. 369). In fact, Celce-Murcia, Dornyei, and Thurrell (as cited in Overfield, 1997, p. 485) noted that the communicative competence is built on actionable, strategic, and sociocultural competences, in addition to the linguistic component (see Figure 1)

Thus, communication is an act that goes beyond its grammar and semantic formulas; rather, it demands the ability to understand the "other".

The following case study comes from a desire to integrate the sociocultural component of language in the EFL classroom for two separate populations. As part of this study, medical students in their third and fourth semester and rural elementary school girls were invited to communicate through pen pal letters. The letters were then analyzed in order to discover how these two different social groups communicated with each other. Specifically, the correspondence yielded patterns in the use of the sociocultural component of communication.
Figure 1

Schematic representation of

Communicative Competence

Schematic Representation of Communicative Competence

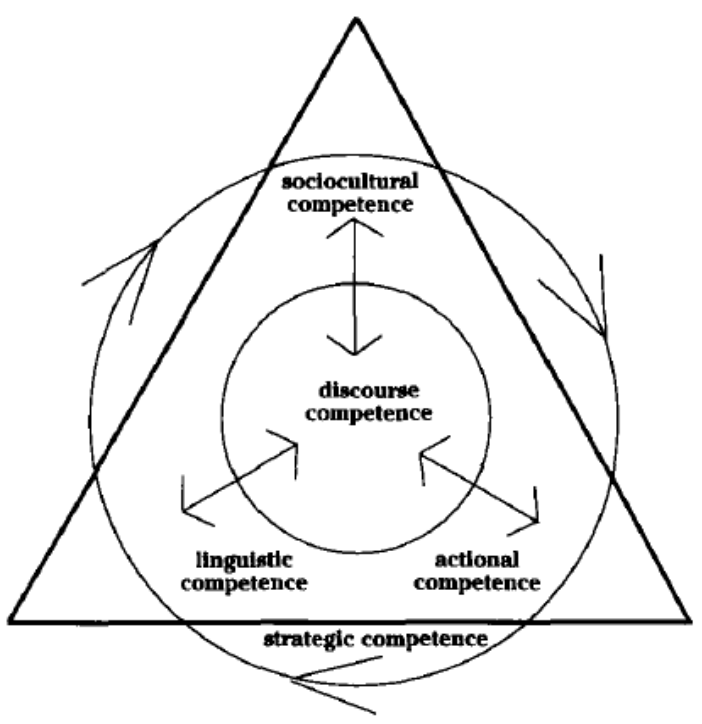

Taken from Celce-Murcia et al. (1993).

As mentioned previously, this case study included two groups of participants. The first was a group of medical students taking the Academic

Writing Course at a public university in Tunja, Colombia. During that time, the medical program sought to implement the "integral education of its students as medical professionals who can respond humanely, scientifically, ethically, and socially to the necessities of the health of our community"4 (Facultad de Medicina, 2018). In addition, the Faculty of Medicine promotes scientific research and community service, which require written and spoken communication skills.

\footnotetext{
${ }^{4}$ Translated by the authors.
} 
Recently, the medical program is facing challenges in transitioning their students from the classroom to the work force.

In a recent interview with a medical student, the following was mentioned:

You know, everyone wanted students from the (public university in Tunja, Colombia), but now, just because of the attitude, other universities are getting more solicited. They are going to make us work harder, uh, I don't really know how that helps with the attitude problem (Interview, Medical student 1, 2018).

This is an issue because continuing to push students academically will not solve the socialization problem faced by the university. In fact, there continues to be a higher emphasis on studying theory than practicing it during the first five semesters of college before entering clinical rotations. Unfortunately, this teaching method has led to students' loss of motivation in their career. As another medical student described,

Obviamente pues yo he tenido muchas dificultades en la carrera pues por el estrés, entonces pues claro, yo tengo mis dudas en cuanto a mi desempeño en la carrera, pero pues, o sea, sigue en mí el deseo de querer pues ayudar a las personas.

[Obviously, well, I have had many difficulties in this career because of stress. So, of course, I have my doubts in terms of my abilities in this career, but well, in other words, I still have the desire to help people.]

(Interview, Medical student 4)

Stress is abundant among the medical students, and it is one of the leading factors of depression. A recent study done at this university showed that $46.6 \%$ of the 782 undergraduate students surveyed displayed symptoms of depression related to somatic-motivational or cognitive-affective factors due to social and academic stressors (Castellanos, Mateus, Cáceres, \& Díaz, 2016). Despite stress and depression associated with their academic studies, students find motivation in thinking about their future. In this case, the students' motivation is to help others, which has kept her from dropping out of medical school.

As a community of scholars, teachers, and administrators, it is important to address affective factors which influence college students in learning new skills, such as communicating with others. If students are provided with a space not only to discuss their feelings, but also to interact with others, affective and social factors may be addressed. Moreover, medical students have a lot to share with their community. One such community is that of elementary school students in rural areas near the university, who can benefit from having role models. Higher education among rural students is often deterred because of economic realities, cultural beliefs, diminished self-worth, lack of motivation, and inaccessibility to knowledge.

Although the second group, made up of elementary school girls, did not face the same affective factors as the medical students, they could benefit from social interactions that could positively influence their thoughts on higher education. In terms of rural education in Colombia, Ramos Holguín and Aguirre Morales (2016) stated, "Another issue related to this is the ideas families have about the education of their children. Some families do not see the relevance of learning more than basic reading, writing and math" (p. 213). Though the girls' families seem supportive of their daughters going to school, there was one case in which one of the girls believed she could not get into 
college given her family's economic situation. Furthermore, only one of the girls had a parent who had received higher education. Ramos Holguín and Aguirre Morales (2016) also added, "Rural students can also lack motivation. The importance of English as a global language remains abstract to students that hardly travel outside their county" (p. 214). Thus, modeling and motivation were the key issues to be addressed with the elementary school girls.

\section{Research Question}

The main purpose of this case study was to analyze how students communicated with each other, and specifically how they developed empathy and role modeling in their attempt to construct and build social relationships by using pen pal letters as a socio-affective learning strategy. Therefore, the study aims at answering the following question:

What do the students' pen pal letters reveal about the way they communicate with each other?

Additionally, we seek to answer the following specific question:

How are empathy and role modeling visible in the pen pal letters and students' reflective discussions?

In the section that follows, we will outline the main theoretical constructs and previous studies necessary in answering the research questions.

\section{Literature Review}

\section{Pen pal letters}

Pen pal letters are letter exchanges between two or more distinct populations.
For the most part, those involved in the letter exchange usually do not know each other at first. Although they are a common practice in schools around the world, there is limited research on the effects of pen pal letters on students. According to Barksdale, Watson, and Park (2007), "Pen pal letter exchanges can support the development of literacy and cultural understandings" (p. 58). In the case of this study, pen pal letters would serve as a cultural exchange between medical students in an urban context and rural elementary school students. Additionally, pen pal letters can be a way for students to develop meaningful and authentic communication with each other. As Barksdale, Watson and Park mentioned, "The benefits of participation in this pen pal exchange have extended well beyond the original purpose of providing an opportunity to practice written language" (p. 66).

\section{Empathy}

One of the studies done on pen pal letter exchanges was between elementary school students in Virginia, United States, and Malawi (Barksdale, Watson \& Park, 2007). This study showed that students demonstrated connections, such as "sympathy, generosity, and compassion" (p. 64). In fact, "the overwhelming desire to make a connection with a pen pal proved to be stronger than the cultural blockades sometimes faced in this project" (p. 64). This could have been due in part to the development of the intercultural competence in pen pal letter exchanges. According to Byram (2008), the intercultural competence "involves empathy and understanding of other perspectives and leads learners, under the guidance of teachers, to challenge existing 
assumptions in their own culture from the perspective of the other" (p. 210).

For this study, we will look at how empathy is displayed as a means of sharing experiences and developing connections between the students. As Reiss (2017) explained, "Empathy plays a critical interpersonal and societal role, enabling sharing of experiences, needs, and desires between individuals and providing an emotional bridge that promotes prosocial behavior" (p. 74).

\section{Role Models and Modeling}

As part of the sociocultural theory proposed by Vygotsky, there are two aspects related to second language acquisition: mediation and imitation. Imitation is defined as "creating something new 'out of saying or doing the same thing" (Newman \& Holzman, 1993, as cited in Lantolf, 2006, p. 91). We highlight that imitation is part of a process of internalizing what we see and hear in society and culture and reproducing it in our "own way". We connect the idea of imitation in second language acquisition with the concept of role modeling. Modeling is the notion of exemplifying behaviors for others to imitate. According to Cruess, Cruess, and Steinert (2008), "role models inspire and teach by example, often while they are doing other things" (p. 718).

Most studies regarding role modeling have been done with medical students during their clinical rotations. Weismann, Branch, Gracey, Haidet and Frankel (2006) provided an example of role modeling between senior faculty and residents. As they mentioned, "Almost every encounter included some affective component introduced by the patient" ( $p$. 663). Furthermore, "Naming the emotion is a standard medical interviewing technique for expressing empathy. Here the technique seemed to take on added power when demonstrated by a senior faculty physician in front of residents" ( $p$. 663). As part of this study, modeling events will be analyzed between the medical students and rural elementary school students. As the needs analysis showed, the medical students have some experience with teaching others, so it is expected that they will try to motivate the rural elementary school students to learn English and further their education after school.

\section{Research Design}

This research study was based on the principles of a qualitative case study. According to Denzin and Lincoln (2000), "Qualitative research is a situated activity that locates the observer in the world. It consists of a set of interpretive, material practices that make the world visible" (as cited in Richards, 2009, p. 149). Furthermore, case studies are based on the notion that a preexisting hypothesis is not considered, although some "ideas" or "expectations" serve as guides for this study (Mouton, 2001, as cited in Ponelis, 2015 , p. 537). In addition, this is both a descriptive and interpretive case study, which is guided by the following criteria:

- Uses a narrative framework that focuses on a real-world problem and provides essential facts about it, including relevant background information.

- Introduces readers to key concepts, policies, and tools (including quantitative tools) relevant to problem. 
- Explains the actual solution, the process of implementation, and the results.

- Offers analysis and evaluation of the chosen solution, its implementation, and the outcomes, including strengths and weaknesses, tradeoffs, and lessons learned.

- May offer alternative solutions to the problem (The Association of Collegiate Schools of Planning, $n$. d., p. 1).

As for using an interpretive approach, Ponelis (2015) mentioned that,

the interpretive research paradigm is characterzed by a need to understand the world as it is from a subjective point of view and seeks an explanation within the frame of reference of the participant rather than the objective observer of the action. (p. 588)

In this case, the data collection instruments reflect the need to look at the data using the students' work as a reference, rather than interpreting the data from a preexisting hypothesis.

\section{Setting and Participants}

There were two groups of participants for this study. The first was a group of three medical students from third and fourth semester at a public university in Tunja, Colombia. There were two females and one male, and they were taking the Academic Writing Course as a way to improve their writing skills for future internship and exchange opportunities. The rural elementary school students consisted of five females whose ages ranged from 5 to 14 , and they came to our class every Friday as part of a community outreach effort. All of the students were residents of Oicatá, a nearby rural town approximately 20 minutes away from the university. In addition, they attended public school in their rural community. The rural elementary school students initially came to the class in order to reinforce their English communication skills, but also because the parents had expressed a desire for their daughters to engage in a meaningful learning environment.

It is important to note that even though the medical students possessed a higher level of proficiency in the English language than the rural elementary school students, both groups were able to communicate through the letters. Both the medical students and rural elementary school students were made aware that they would be part of the study. Any names that appear in this study have been changed to pseudonyms in order to protect the identity of the participants. Additionally, the parents of the rural elementary school girls signed consent forms as part of the ethical considerations for this research study (see Annex 1).

\section{Data Collection}

The data was collected through the use of three instruments: students' artifacts, field notes, and discussions. The students' artifacts consisted of the pen pal letters and their content. The medical students initiated writing the letters with the indication that they had to address the letter as "Dear Someone". At this point, the reader remained anonymous. The second round of letters were the rural elementary school students' response. At first, we, the teacher-researchers, gave the letters to the students so they could have time to review the content. Then, we individually sat down and read through the letters with each student. In case they 
needed help with new vocabulary found in the letters, they could ask us for help. The students were encouraged to write according to what they wanted to say either in the L1 or L2. If the rural elementary school students wanted to respond in English, they could also solicit the vocabulary they felt they needed. In this case, we would either guide them on how to use the dictionary or write the new word or phrase on the board. Thus, the letters reflected the language they wanted to use. The third round of letters was the response from the medical students, and the fourth round was the response from the rural elementary school students.

During this process, we took field notes that were both descriptive and reflective. They were descriptive in nature because they described actions, expressions, and experiences lived during the letter writing process. They were also reflective, as we both took time to think about how the activity had affected the students. The final instrument was a reflective discussion provided by the medical students and rural elementary school students. The rural elementary school students and medical students provided a reflective discussion through a semi-structured interview.

\section{Data Analysis}

The analysis of the data was based on parts of the grounded theory approach, which "involves the progressive identification and integration of categories of meaning from data" (Willig, 2013, p. 70). First, the students' artifacts were organized, and common patterns were identified. This was achieved by colorcoding the content in the letters and by defining similar categories. Then, we looked at the field notes and identified similar patterns that had emerged in the initial analysis of the letter content.
Finally, we looked at the students' reflective discussion responses in relation to the patterns found in the students' artifacts and field notes. Once the data was categorized, a table was developed to show how the categories and subcategories related to answering the research questions.

\section{Results}

After analyzing the results obtained from the student' artifacts, field notes, and discussions, four categories emerged. These categories were then divided into the research question or sub question that they answered. The chart below shows the division of the categories.

Table 1

Categories and subcategories table and their correspondence to the research questions.

\begin{tabular}{|c|c|c|}
\hline $\begin{array}{l}\text { Research } \\
\text { Questions }\end{array}$ & Categories & Subcategories \\
\hline \multirow{3}{*}{$\begin{array}{l}\text { What do } \\
\text { students' pen pal } \\
\text { letters reveal } \\
\text { about the way } \\
\text { they } \\
\text { communicate } \\
\text { with each other? }\end{array}$} & All About Me & \\
\hline & What About & Connections \\
\hline & & $\begin{array}{l}\text { Referential } \\
\text { questions }\end{array}$ \\
\hline \multirow{4}{*}{$\begin{array}{l}\text { How are } \\
\text { empathy and } \\
\text { role modeling } \\
\text { visible in the pen } \\
\text { pal letters and } \\
\text { students' } \\
\text { reflective } \\
\text { discussions? }\end{array}$} & \multirow[t]{2}{*}{$\begin{array}{l}\text { I Hope You } \\
\text { Are Ok }\end{array}$} & $\begin{array}{l}\text { Encouraging } \\
\text { statements }\end{array}$ \\
\hline & & Concern \\
\hline & \multirow{2}{*}{$\begin{array}{l}\text { Never } \\
\text { Change }\end{array}$} & Advice giving \\
\hline & & Modeling \\
\hline
\end{tabular}




\section{All About Me}

This category emerged from patterns found in the initial letters written by the medical students, which mostly gave information about themselves. Thus, we titled this category All About Me. As mentioned previously, the medical students started the pen pal letter exchange, and their only indication was that they had to direct the letter as "Dear Someone". In other words, the reader of the letter remained anonymous. Furthermore, they were asked to draw a picture that described themselves on the other side of the letter. The letters show that they initiated with information about themselves. For the most part, the letters started with their name, age, and their identity as medical students, which can be seen in the excerpts below.

\section{Excerpt 1}

My name is Carlos. I have 20 years old, and I'm a medical student, a happy med student. Well, sometimes. [sic] (Students' artifacts, Medical Student 3, Letter 1)

Excerpt 2

My name is Laura. I am 22 years old. I am a medical student in Tunja, Boyacá. [sic] (Students' artifacts, Medical Student 1, Letter 1)

\section{Excerpt 3}

My name's Viviana, but you can call me Vivi, because this is my nickname. I'm 20 years old and I really happy at this moment of my live, why? Why not? I gonna tell you a little of my life. Now a day, I study medicine. [sic] (Students' artifacts, Medical Student 2, Letter 1)

This first introduction was important because it indicated that the medical students defined themselves as medical students before any other characteristic. In the case of Excerpt 1 and
3 , there was an indication of emotion attached to their identities as medical students. Excerpt 1 showed a state of happiness, followed by a second evaluation, "Well, sometimes". Excerpt 3 showed happiness as well, followed by a question statement and a final declarative "Why not?" The content of the letters also showed an explanation of likes, such as interests in medical research, language, and music.

In one case, Medical Student (hereinafter MS) 3 used an expressive to declare his opinion about music (see Excerpt 4), which could influence his reader's response. Additionally, we saw a declaration of identity in their affiliation to music. In the case of MS 3, there was a disassociation with popular music and typical music heard in Colombia.

\section{Excerpt 4}

I don't like to listen to popular music. I think that is bored and ugly. I hope you listen good music. Specially metal music. However, not typical music. [sic] (Students' artifacts, MS 3, Letter 1)

Figure 2

MS 2's drawing of what identifies her.

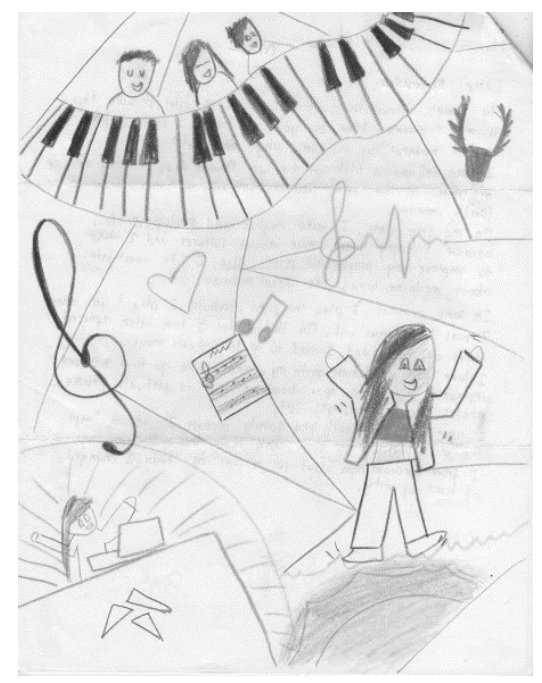


As seen in Figure 2, MS 2 identified herself as a pianist and showed that in her drawing as well. Moreover, she drew herself in a lab coat, which displayed her identity as medical student once more. Additionally, two of the letters indicated that the medical students live on their own in the city, as their families lived in another region of the country, as seen in the excerpt below.

\section{Excerpt 5}

I love pass time with my family because I live in Tunja the most part of the year and They live in Bucaramanga. [sic] (Students' artifacts, MS 2, Letter 1.)

Finally, it was important to note that only two of the three letters made any reference to the reader. Only MS 1 asked referential questions (see Excerpt 6) regarding the reader.

\section{Excerpt 6}

What do you study? Do you have any hobbies? I hope to hear from you soon! [sic] (Students' artifacts, MS 1, Letter 1)

For the most part, the initial letters touched upon topics, such as school, likes, and family. They showed how the medical students identified themselves when talking to an unknown reader. At the same time, only one of the letters asked for more information from the reader. This could be due to the fact that the reader was unknown, or they assumed that the reader would be the teacher. In the case of the latter, students were rarely in a position to ask the teacher, in other words us, personal questions, which was exemplified in their letters.

\section{What About You, Friend?}

This category comes from the questions asked by the rural elementary school students (hereinafter RS) in their response letters, denoted as Letter 2. We reiterate that the RSs were at a beginner level of English. Therefore, their response letters were primarily written in their mother tongue or L1, which is Spanish. Most of the vocabulary in English came from their own background knowledge or by asking the teachers. Given the information obtained the response letters, we obtained the following subcategories: connections and referential questions.

In terms of connections, all of the five RSs developed some form of connection with the medical students. Below are some examples of the types of connections established:

Figure 3

\section{Closing statement in $R S 1$ response letter.}

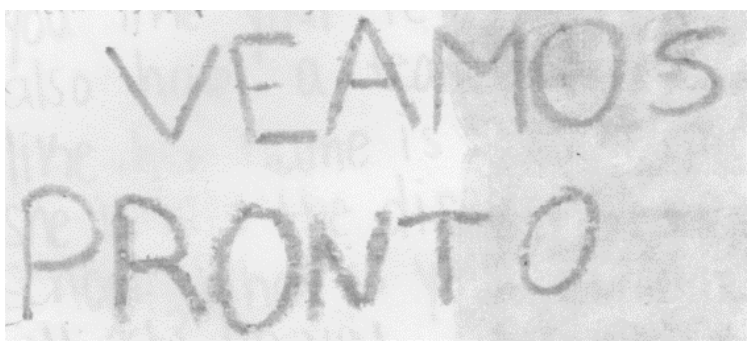

Figure 4

\section{Closing statement in RS 5 response letter.}

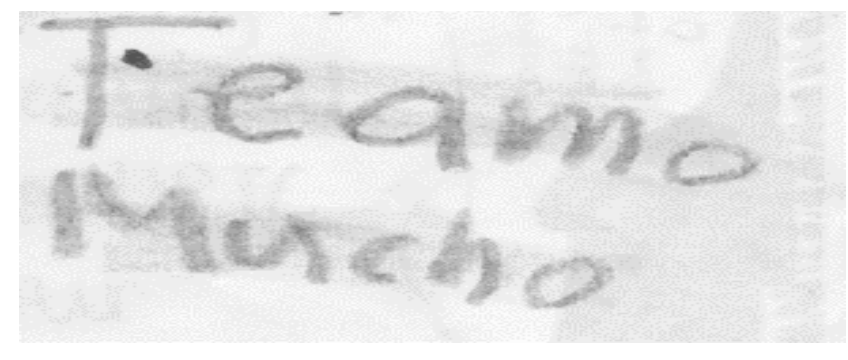

\section{Excerpt 7}

My name is Jessica, but you can call me Jessi..... study music and me encanta...... like to study medicine. [sic] (Students' artifacts, RS 4, Letter 2) 
Excerpt 8

Me gustaria estudiar la Animacion [I would like to study animation], I like to travel too... I like to electronik music. [sic] (Students' artifacts, RS 3, Letter 2)

Figure 3 and 4 demonstrated how the RSs tried to build an affiliative connection with the MSs. Figure 3 translated to "let's see each other" in English, while Figure 4 translated to "I love you very much". In both cases, there was an establishment of friendship and love for the other person.

Meanwhile, Excerpt 7 showed a connection to what was written by MS 2 . As mentioned in the previous category, MS 2 identified herself as a pianist and music lover. Consequently, RS 4 mentioned that she also liked to study music, and she loved it. Likewise, she made a statement concerning her own connection to medicine. In Excerpt 8, RS 3 connected with MS 3's desire to travel, as well as his statement about music (see Excerpt 4). In both cases, it was important to note that both RSs made a reference to what they liked or wanted to study after school. This was a meaningful aspect, especially since RS 4 had expressed earlier that she could not go to college because of her family's economic situation.

Only one of the letters contained a referential question from RS 5, who asked, "qué te gusta?" [What do you like?]. Therefore, the pattern observed here was the common lack of referential questions in the letters. This notion shed light on the previous belief that the medical students did not ask for more information due to their position as students. Rather, we noticed that the students preferred to provide information about themselves in their response letters.
In the second response letters provided by the RSs, designated as Letters 4 , there was a change in the pattern. In fact, four out of the five RSs asked several referential questions. This phenomenon was explained in the field notes below:

\section{Excerpt 9}

Two of the students were so excited, and at the same time afraid of making mistakes, they asked, "How do I ask what food do they like to eat? What is their favorite color? Do they have pets?" (Field notes, Teacher 1)

Thus, two of the RSs demonstrated a desire to know more about the MSs, which resulted in asking for the vocabulary needed to ask personal referential questions. In writing the vocabulary on the board, another two RSs decided to include referential questions in their own letters.

\section{Hope You Are Ok}

This category came from a general pattern that appeared in the letters that followed Letter 1. Two subcategories emerged (encouraging statements and concern), which were displayed by both groups. The following excerpts show encouraging statements and acts of concern displayed in Letter 2.

\section{Excerpt 10}

Espero que estes bien que te saques buenas calificaciones....que te vaya bien te quiero friends [I hope you are well and you get good grades.....I hope everything goes well I love you friend] [sic] (Students' artifacts, RS 2, Letter 2)

\section{Excerpt 11}

Amiga te quiero mucho. Como estas amiga [Friend I love you. How are you] [sic] (Students' artifacts, RS 5, Letter 2) 
The idea of concern and encouragement in Letter 2 dealt with how the students asked each other how they were. In the case of Excerpt 10, we interpreted that the meaning of asking how the other person was goes beyond a mere formality, which is common in spoken dialogue. Rather, it was meant as a concern statement, since what followed was a specific desire for the other to do well in school. Concern and encouraging statements were mirrored in the MSs second letter, represented as Letter 3 in Excerpt 12.

\section{Excerpt 12}

I hope you be ok, and have a great year. Remember that study what you like is too important. [sic] (Students' artifacts, MS 3, Letter 3)

For the most part, the type of concern and statements of encouragement from the MSs were more closely related to giving advice, which was seen in the following category.

\section{Never Change}

For this study, we were expecting to see role modeling behavior in terms of language use, which was related to imitation of the language. In a sense, this was apparent in the way the RSs introduced themselves (see Excerpt 3 and 7). What was unexpected was the way the RSs and MSs mirrored each other's behavior predominantly in the imagery they used in the letters. This gave way to the subcategory role modeling. What's more, we did not expect the MSs to take on a role of advice givers. This was the main way in which they conveyed concern, albeit positioning themselves as someone who has lived more experiences. Therefore, the second subcategory that emerged was titled advice giving. We reiterate once again that these ideas were not imposed or suggested during the study. Our role as teachers was only to provide vocabulary asked for by the students.

In terms of role modeling, the initiators of the communication were the MSs since they provided the first drawings. Below is a progressive series of pen pal letter drawing from MS 3 and RS 3 ranging from Letter 1, 2, 3, and 4 in sequential order.

Figure 5

Progression of letter imagery between MS 3 and RS 3.

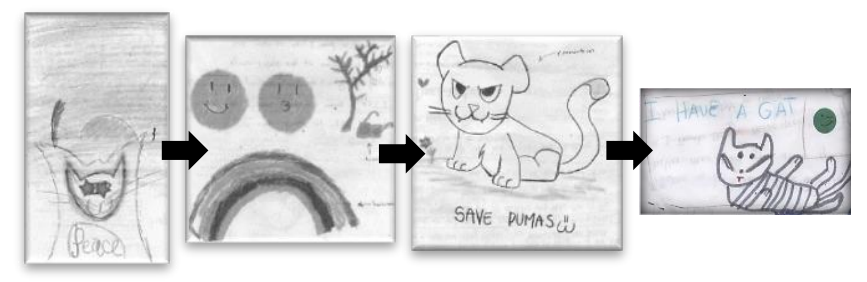

Note. The images from left to right correspond to MS 3 (Letter 1), RS 3 (Letter 2), MS 3 (Letter 3), and RS 3 (Letter 4).

As seen in the drawing, MS 3 started off with a cat wearing sunglasses in front of a tree and rainbow sky. RS 3 also drew a rainbow, tree, and sunglasses. Here, we saw a case of imitation, where RS 3 took elements from MS 3, but made them her own. After RS 3 wrote in her letter that her favorite animal was the puma, MS 3 drew a puma in Letter 3. Then, RS 3 continued the conversation about pumas and the environment, and she drew her cat.

A similar case is provided in the progression of correspondence between MS 2 and RS 2, seen below,

Figure 6

Progression of letter imagery between $M S$ 2 and $R S 2$. 


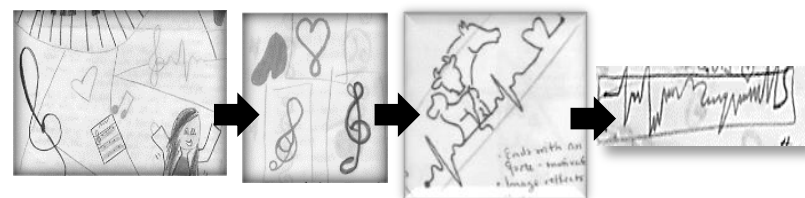

Note. The images from left to right correspond to MS 2 (Letter 1), RS 2 (Letter 2), MS 2 (Letter 3), and RS 2 (Letter 4).

In this case, we saw a musical note drawn by MS 2, which was then imitated several times by RS 2 given her own interpretation. MS 2 connected with her own career and that of RS 2, who mentioned that she wanted to be a veterinarian. Thus, MS 2 drew an EKG graph with animals and a heart. RS 2 also imitated the EKG graph and added the heart as well.

It was interesting to see that, for the most part, language was imitated, but not as much as expected. Rather, images were the most copied by the RSs, although in all of the cases they were changed. We were able to see how the MSs were positioned by the RSs as role models in language use, career choices, and drawing imitation. The following excerpts demonstrated the second subcategory, which related to how students provided advice to each other.

When the MSs found out their letters had been answered by a groups of rural elementary school girls, they were very surprised. The following field notes described that moment:

\section{Excerpt 13}

The students were so excited to receive their letters. They couldn't believe that I had given it someone else. They clapped and were smiling when they got the letters back. Together, they made a video for the students with inspiring messages, like "Be good" and "Follow your dreams". (Field notes, Teacher 2)

Thus, the MSs took on a position of not only being role models, but also teaching the RSs about life. As MS 3 reflected,

Excerpt 14

If you teach children empathy, they will never be a bad person. [sic] (Reflective discussion, MS 3)

\section{Excerpt 15}

You are a little girl, but you will grow up and the most important things is that you must be a good person. [sic] (Students' artifacts, MS 3, Letter 3.)

From these excerpts, we saw that MS 3 had a strong conviction that what matters in life was being a good person, which he reflected in both his letter (see Excerpt 15) and reflective discussion. The following excerpts also showed other types of advice given by the medical students.

\section{Excerpt 16}

I hope, you enjoy study and got to school, because in this way, you can be a very good professional and study veterinary medicine. Enjoy these childhood years, at least you will know it, you will have grown and probably you will miss some things of this stage. [sic] (Students' artifacts, MS 2, Letter 3)

In Excerpt 16, we noticed that advice was related to studying and life. Unexpectedly, the RSs also provided advice. In Excerpt 17, we saw a case where language was imitated by RS 4 from the advice provided by MS 2. Yet, Excerpt 18 showed how RS 3 provided her own advice unrelated to what had been mentioned by MS 3.

\section{Excerpt 17}

Continue with your study and meet your goals [sic] (Students' artifacts, RS 4, Letter 3) 


\section{Excerpt 18}

I promise you a will never change. Never change. [sic] (Students' artifacts, RS 3, Letter 3)

These last excerpts were unexpected for us because we did not think that the RSs would give advice. For the most part, children are not expected to be advice givers because it is not their societal position to do so. Instead, children are associated with being advice receivers. The following field notes demonstrated our reflections on how the pen pal letters served, in a sense, as equalizers in terms of positioning.

\section{Excerpt 19}

The letters were like a treasure for them. It was really nice. They were giggling, and I could see the smile and satisfaction on their faces. They got so involved in writing the letter that they forgot they were little. It is incredible to see how writing can get people closer, happier, and more creative. (Field notes, Teacher 2)

As the field notes summarized, the RSs "forgot they were little", and they made an effort to communicate keeping their reader in mind. The pen pal letters actually made the RSs take risks in making friends and communicating with someone outside of their social group without the pressure of having them face-to-face. As RS 2 reflected about the letter writing process,

\section{Excerpt 20}

Un poco de nervios y un poco emocionada porque, pues, emocionada porque uno conoce un nuevo amigo, pero pues nervios porque puede ser que no le guste lo que le pregunte o lo que le diga [A bit of nerves and a bit of excitement, well, excitement because you meet a new friend, but nervousness because it could be that they don't like what you asked them or what you told them]. [sic] (Reflective discussion, RS 2)

\section{Conclusion}

The pen pal letters, field notes, and reflective discussions have all shown how the medical students and rural elementary school students were able to communicate despite never having met face-to-face. There are some aspects of the communication that took place which connects to how we communicate with others, such as introductions and asking for more information. Nonetheless, the pen pal letters also demanded risk taking, identity construction, and positioning. The following list summarizes the main conclusions based on the results of this study:

1. Despite being written discourse, the pen pal letters fostered real and authentic communication based on the language the students wanted to use.

2. The first letters displayed information about the medical students, who identified themselves as medical students before mentioning any other identifiers.

3. The emotional benefits of having a pen pal appeared in the letters, students' reactions, and reflective discussions.

4. The girls changed their perspectives about higher education, as many of them now talk about having a professional career after the pen pal letter exchanges.

5. Pen pal letters can be a means of making friends with other social groups, thereby fostering intercultural awareness in our own communities. They also take the 
pressure away from face-to-face interaction with a stranger.

6. Despite having different language levels, both groups of students were able to communicate. The rural elementary school students felt challenged to provide more words in English in order to continue the written conversation with the medical students.

7. Both groups felt empowered to position themselves as advice givers, something which is uncommon for college students and children.

8. The pen pal letters can serve as a tool for modeling positive behaviors, which can affect how young rural elementary school children construct their identities.

As a final conclusion, we add that this experience helped change lives. The medical students expressed that this experience was very meaningful for them, as did the rural elementary school students. In addition, this is a crucial period in identity construction for both groups, for which pen pal letters could help in defining identities and empowering students. In doing so, students create meaningful relationships based on all of the aspects of communication.

Sometimes, as teachers, we struggle because we do not have the best equipment, the fastest internet, or even native speakers to rely on. In reality, we have many role models in our community waiting to be heard, starting with our children and college students, who also benefit from the social aspect of communication. As for the necessary equipment, a piece of paper, some colors, and a world of imagination are more than enough.

Byram, M. (2008). From foreign language education to education for intercultural citizenship: Essays and reflections. Bristol, UK: Multilingual Matters. https://c.ymcdn.com/sites/www.ac sp.org/resource/resmgr/files/Linco In_Awards/Descriptive_Case_Te mplate.pdf

Barksdale, M. A., Watson, C., \& Park, E. S. (2007). Pen pal letter exchanges: Taking first steps toward developing cultural understandings. The Reading Teacher, 61(1), 58-68.
Castellanos, V., Mateus, S. M., Cáceres, I. R., \& Díaz, P. A. (2016). Caracterización de la depresión en estudiantes universitarios. Revista Salud Historia y Sanidad, 11(1), 37-50. 
Cruess, S. R., Cruess, R. L., \& Steinert, Y. (2008). Role modeling making the most of a powerful teaching strategy. $B M J, 336,718$ 721.

Facultad de Medicina. (2018). MisiónVisón. Retrieved from http://www.uptc.edu.co/facultades /f_salud/pregrado/medicina/inf_ge neral/

Fandiño Parra, Y. J. (2009). Explicit

teaching of socio-affective language learning strategies to beginner EFL students. Íkala, revista de lenguaje y cultura, 15(24), 145-169.

Lantolf, J. (2006). Sociocultural theory and L2: State of the art. Studies in Second Language Acquisition, 28(1), 67-109.

Munodawafa, D. (2008). Communication: Concepts, practice, and challenges. Health Education Research, 23(3), 369-370.

Overfield, D. M. (1997). From the margins to the mainstream: Foreign language education and community-based learning. Foreign Language Annals, 30(4), 485-491.

Ponelis, S. R. (2015). Using interpretive qualitative case studies for exploratory research in doctoral studies: A case of Information Systems research in small and medium enterprises. International Journal of Doctoral Studies, 10, 535-550. Retrieved from http://ijds.org/Volume10/IJDSv10 p535-550Ponelis0624.pdf

Ramos Holguín, B., \& Aguirre Morales, J. (2016). English language teaching in rural areas: A new challenge for English language teachers in Colombia. Cuadernos de Lingüística Hispánica, (27), 209-222.

Reiss, H. (2017). The science of empathy. Journal of Patient Experience, 4(2), 74-77.

Richards, K. (2009). Trends in qualitative research in language teaching since 2000. Language Teaching, 42(2), 147-180.

Weismann, P.F., Branch, W.T., Gracey, C.F., Haidet, P., \& Frankel, R. M. (2006). Role modeling behavior humanistic behavior: Learning bedside manner from the experts. Academic Medicine, 81(7), 661667.

Willig, C. (2013). Introducing qualitative research in psychology ( $3^{\text {rd }}$ ed.). New York, NY: Open University Press. 


\section{ANNEX 1: Consent Form}

Señores

Queridos padres,

Es para solicitarles su consentimiento para llevar a cabo un proyecto de investigación. Este proyecto tiene como propósito mostrar como la comunidad puede aprender sobre el idioma, la empatía, y los valores a través de las estrategias de aprendizaje. La participación de las estudiantes es totalmente voluntaria.

De antemano, les quiero agradecer por todo su apoyo en realizar este estudio. También les quiero comentar que el nombre de las estudiantes no aparecerá en la investigación, ni ninguna información personal, solo la información pertinente en los escritos y entrevistas sobre el tema de investigación.

¡De antemano, les agradecemos su participación! Si tienen alguna pregunta, no duden en contactarnos.

Atentamente,

Si está de acuerdo que su hija participe en este estudio, por favor firmen en esta línea. 